ANADOLU, J. of AARI

ISSN: 1300-0225 (Print)

E-ISSN: 2667-6087 (Online)

2020, 30 (1): 94-102

DOI: $10.18615 /$ anadolu. 727249

\title{
Çifţ̧i Koşullarında Yerel Çeşitlere Dayalı Buğday Üretimi
}

\author{
Asuman KAPLAN EVLICE ${ }^{1^{*}}$ (D) Aydin AKKAYA ${ }^{2}$ \\ ${ }^{1}$ Tarla Bitkileri Merkez Araştırma Enstitüsü, Ankara/TURKEY \\ ${ }^{2}$ Kahramanmaraş Sütçü İmam Üniversitesi, Ziraat Fakültesi, \\ Tarla Bitkileri Bölümü, Kahramanmaraş/TURKEY \\ ${ }^{1}$ http://orcid.org/0000-0002-0344-6767 $\quad{ }^{2}$ http://orcid.org/0000-0001-9560-1922 \\ * Corresponding author (Sorumlu yazar): asuman.kaplanevlice@tarimorman.gov.tr \\ Received (Geliş tarihi): 07.10.2019Ａccepted (Kabul tarihi): 27.12.2019
}

\begin{abstract}
ÖZ: Ülkemizde, özellikle son 50 yıllık süreçte yeni buğday çeşitlerinin yaygınlaşması, yerel popülasyonların üretimdeki paylarının giderek azalmasına yol açmıştır. Ancak, son yıllarda üretim sistemleri ve talepteki yeni yönelmeler nedeniyle, yerel buğday çeşitlerimiz üretim için yeniden güncel duruma gelmiştir. Bu nedenle, yeni çeşitler yerine yerel çeşitlere dayalı buğday üretiminin, potansiyel risk ve firsatlar açısından değerlendirilmesi yararlı olacaktır. Yeni buğday ve yerel buğday konusundaki değerlendirmelerde, bir diğerini faydasız sayan karşılaștırma, tartışma ve yaklașımlardan uzak durulmalıdır. Buğdayın yıllık üretim miktarı riske sokulmamalı ve yüksek verimli yeni çeşitlerin, artan nüfusun gıda güvenliğinin sağlanmasındaki önemi unutulmamalıdır. Bu nedenle, yüksek tane verimi sağlayabilme potansiyeline sahip koşullarda yapılacak buğday üretiminde, yeni çeşitler yerine yerel çeşitlerin tercih edilmesi riskli olacaktır. Aksine yerel çeşitler; geleneksel yetiştiriciliğe rağmen düşük verim alınan koşullar, yüksek sap üretimi istenilen durumlar, yerel taleplerin yüksek olduğu yöreler, özellikle de organik buğday tarımı için üretim firsat ve potansiyeline sahiptir. Bilimsel ve üretici katılımlı çalışmalarla bu firsatlar ve potansiyeller değerlendirilebilir, ıslah açısından büyük bir öneme sahip olan yerel buğdaylara dayalı ekonomik ve sürdürülebilir üretim sağlanabilir.
\end{abstract}

Anahtar Kelimeler: Yerel buğdaylar, tane ve sap verimi, organik tarım, kalite.

\section{Wheat Production Based on Landraces in Farmer Conditions}

ABSTRACT: The widespreading of modern wheat cultivars, especially throughout last 50 years in Turkey, have caused to progressively decrease the proportion of landraces in production. However, Turkish wheat landraces have been popular again for production because of new trends in production systems and demands in recent years. Therefore, it will be useful to consider the potential risks and opportunities of wheat production based on landraces instead of modern varieties. In considerations on modern wheat varieties and landraces, it should be avoided from comparison, discussing and approaching making each other useless. The annual production of wheat should not be put at risk, and it should not be forgotten the importance of high yielding modern wheat varieties in providing the food security for increasing population. For this reason, the preferring the landraces instead of modern varieties will be risky in wheat production to be performed in conditions capable of providing the high grain yield. On the contrary, the landraces have the production opportunities and potentials; in low yielding conditions despite the conventional farming system, for situations desiring the high straw yield, in places with high local demands, and especially for organic wheat farming. These opportunities and potentials could be considered in scientific and farmer participatory studies, and it could be provided the economic and sustainable production based on wheat landraces with great importance in terms of breeding.

Keywords: Wheat landraces, grain and straw yields, organic farming, quality. 


\section{GíRiş}

Ülkemiz buğdayın gen merkezi olup, diploid buğdaylar ilk olarak Güneydoğu Anadolu Bölgesi'nde kültüre alınmış ve Karacadağ orijinli materyaller üzerinden dünyaya yayılmıştır (Karagöz ve Özberk, 2010). Ülkemizdeki genetik kaynaklar, çok sayıda yerli ve yabancı araştırıcıların ilgisini çekmiş olup, bu ilgi halen artarak devam etmektedir. Yerel popülasyonlar ve genetik kaynaklar çeşitli yönlerden incelenmiş ve sslah amaçlı kullanım olanakları belirlenmeye çalışılmış (Karademir ve Sağır, 1999; Alp ve Akıncı, 2005; Alp ve Aktaş, 2005), yerel buğday popülasyonlarında varyasyonun oldukça yüksek olduğu çeşitli araştırmalarla ortaya koyulmuştur (Zencirci, 1995; Damania ve ark., 1996; Alp ve Kün, 1999; Karagöz ve Zencirci, 2004; Sudutan, 2009).

Hastalık ve zararlılar, ekonomik koşullar, talep, teknolojik ve bilimsel gelişmeler, iklim ve çevre koşulları gibi faktörlerde; zamana bağlı olarak ortaya çıkan değişiklikler, çeşit ıslahında sürekliliği zorunlu hale getirmekte ve sürekli yeni çeşit talebi ve ihtiyacı yaratmaktadır. Bu talep ve ihtiyaç, çok sayıda yeni buğday çeşitlerinin ticarileşmesine ve üretime girmesine neden olmuş ve olmaya devam etmektedir. Yeni ticari buğday çeşitlerinin yaygınlaşmasına neden olan bu süreç, özellikle son 50 yılda, yerel popülasyonların aleyhine bir durum yaratmış ve giderek üretimdeki paylarının azalmasına, hatta üretimden çekilmelerine yol açmıştır (Akkaya, 2008).

Yeni buğday çeşitlerin üretiminin yaygınlaştığı süreçte, tarımsal kimyasal kullanımı da önemli düzeyde artarak; geleneksel tarım, çevre ve insan sağlı̆̆ için tehditler oluşturmaya başlamıştır. Geleneksel tarımda yoğun bir şekilde kullanılan kimyasalların, çevre ve insan sağlığı üzerindeki olumsuz etkileri görüldükçe, üretim sistemlerinde esaslı değişikliler ve arayışlar ön plana çıkmıştır. Sadece yüksek verimi esas alan, ancak doğal dengeyi bozan, çevre ve insan sağlığını olumsuz etkileyen geleneksel üretim sistemleri yerine, sürdürülebilir tarım, organik tarım gibi üretim sistemleri güncel duruma gelmiş ve uygulamada giderek yaygınlaşmaya başlamıştır. Geleneksel üretim sistemlerinden çevre dostu üretim sistemlerine doğru olan bu yöneliş, yerel buğday çeşitleri için yeni firsatları da beraberinde getirmiştir. Islah amaçlı olarak zaten çok büyük değer taşıyan yerel buğday materyalimiz, üretim sistemleri ve talepteki yeni yönelişler nedeniyle üretim amaçlı olarak da yeniden güncel duruma gelmişlerdir.

$\mathrm{Bu}$ çalışma ile yerel çeşitlere dayalı buğday üretiminin ele alınarak, taşıdığı potansiyel risk ve fırsatların iki yönlü tartışılmasının yararlı olacağ1 düşünülmüştür.

\section{KATILIMCI ISLAH}

Yerel buğday çeşitleri, çiftçiler tarafindan geleneksel yöntemler kullanılarak geliştirilen, doğal seleksiyonun da etkisiyle belli bir yöreye uyum sağlamış olan popülasyon niteliğine sahip genotiplerdir (Zencirci, 2018). Ülkemiz buğday materyalleri üzerindeki ilk çalışmalar Gökgöl ve Zhukovsky tarafindan yapılmış (Karagöz ve Özberk, 2010), yerel popülasyonlar ve genetik kaynaklar çeşitli yönlerden incelenerek, bu materyalin 1slah amaçlı kullanım olanakları belirlenmeye çalışılmıştır (Karademir ve Sağır, 1999; Alp ve Akıncı, 2005; Alp ve Aktaş, 2005). Hastalıklara karşı dayanıklı çeşit geliştirmede, düşük girdili koşullara ve organik tarıma uygun çeşit islahında yerel çeşitlerden ve yabani türlerden yararlanıldı ̆̆ 1 rapor edilmiştir (Murphy ve ark., 2007; Lammerts van Bueren ve ark., 2011). Yapılan çalışmalarda yerel buğday popülasyonlarında varyasyonun oldukça yüksek olduğu tespit edilmiş (Zencirci, 1995; Damania ve ark., 1996; Alp ve Kün, 1999; Karagöz ve Zencirci 2004) ve yerel genotiplerin protein oranı, koleoptil uzunluğu, tuza tolerans, erkencilik, mineral madde içeriği, antioksidan, lutein miktarının artırılması, kurağa ve hastalıklara dayanıklılık bakımından 1slah programlarında gen kaynağı olarak kullanılabileceği belirtilmiştir (Salantur, 2018).

Ülkemizde, araştırma kurumları tarafından yerel buğday popülasyonlarından seleksiyon 1slahı yöntemiyle; Ak 702, Sertak 52, Sivas 111-33, Yayla 305, Ankara 093-44, Köse 220-39 ekmeklik 
buğday çeşitleri ve Sarıbuğday 710, Akbaşak 07344, Kunduru 414-44, Sarıbursa 7113, Karakılçık 1133, Fata "S" 185-1, Kunduru 1149 makarnalık buğday çeşitleri geliştirilmiştir (Salantur, 2018). Yerel popülasyonlardan seleksiyonla geliştirilmiş olan Kunduru-1149 çeşidinin, makarna kalitesi yönünden çok önemli olan $\gamma-45$ gliadin ve LMW-2 glutenin proteinlerine sahip olduğu belirlenmiştir (Y1ldirım ve ark., 2008).

Dünyada genetik materyallerin önemi her geçen yıl biraz daha artmakta, başta yerel popülasyonlar olmak üzere bütün gen kaynakları korunmaya çalışılmaktadır. Koruma yöntemlerinden birisi de yerinde muhafaza olup, ülkemizde de bu yönde çalışmalar söz konusudur (Karagöz, 1998; Aykas ve Tan, 2018). Genetik kaynakların korunması açısından, gen bankaları ve çiftçi koşullarındaki koruma birbirlerini tamamlayıcı olmaktadır (Hammer ve Diederichsen, 2009).

Islah programlarındaki önemli ve yararlı yaklaşımlardan birisi çiftçi katılımlı ıslah programıdır. Düşük girdili koşullara ve organik buğday tarımına uygun, özel adaptasyon yeteneğ yüksek çeşit geliştirmede, yetiştiricilerin de ıslah programlarına katılması halinde daha başarılı sonuçlara ulaşıldığ $\breve{1}_{1}$ belirtilmiştir (Banziger ve Cooper, 2001; Kandel ve ark., 2008). Yetiştirici katılımlı 1slah programlarının; yetiştirici bilgi birikimlerinin sslah stratejilerinde dikkate alınması, araştırıcıların bilimsel birikimlerinin çiftçi uygulamalarına aktarılması, çiftçi koşullarındaki genetik farklıı̆̆ın korunması, artırılması ve sürdürülebilir tarım bakımından önemli yararlar sağlaması söz konusudur (Ashby, 2009).

Bazı buğday yerel çeşitlerinin korunması ve günümüze kadar taşınmasında, yöresel lezzetlerin olmazsa olmazı anlayışı çok etkili olmuş (Tan, 2018), buğday gen kaynaklarımızın, atalarımızın mirası anlayışı yerine, gelecek nesillerin emaneti bilinciyle korunması gerektiği vurgulanmıştır (Özdemir ve ark., 2018). Çiftçilerin yerel çeşitleri yetiştirmesinde fiziki koşullar, toprak, iklim, sosyo-ekonomik, pazarlama, fiyat politikaları, özel ürün ve gıdaların üretimi, verim, risk, kalite, hastalık, zararlı ve olumsuz koşullara dayanıklılık gibi birçok unsurun etkili olduğu, yapılacak programlarda başarı için çiftçilerin mutlaka sürece katılmaları gerektiği belirtilmiştir (Karagöz, 2018).

\section{TANE VERIMII}

Üreticilerin, yeni buğday çeşitleri ve yerel buğday çeşitleri arasında yaptıkları tercihte etkili olan en önemli faktörlerden birisi: birim alandan elde edilen tane verimidir. Geleneksel üretim koşullarında tane verimi yönünden, yeni çeşitler yerel çeşitlere karş1 mutlak denilecek bir üstünlüğüne sahiptir. Çünkü yeni buğday çeşitleri genellikle verimli koşullar, yani geleneksel tarım sistemleri esas alınarak ıslah edilmişlerdir. Özellikle kısa boylu buğday çeşitlerinin 1slahı yeşil devrime yol açmış, fazla gübre ve su kullanımına bağlı yatma yönünden hemen hemen hiçbir risk kalmamıştır.

Ülkemize yönelik değerlendirmelere esas olmak üzere bazı rakamların verilmesi yararlı olacaktır. Ülkemizde son 17 yıllık dönemde, yıllık buğday üretimi 17,2-22,6 milyon ton arasında değişmiş, en düşük üretim 2007 yılında, en yüksek üretim 2015 yılında gerçekleşmiştir. Y1llık en yüksek üretimin gerçekleştiği 2015 yılı esas alındığında, geleneksel buğday tarımında ortalama tane verimi kuru/sulu koşullarda sırasıyla, makarnalık buğdaylarda 247/466 $\mathrm{kg} / \mathrm{da}$, ekmeklik buğdaylarda 244/412 kg/da olmuştur. Aynı yıl, örneğin Erzurum'da il ortalaması olarak buğday verimi kuru/sulu koşullarda 135/232 $\mathrm{kg} / \mathrm{da}$, Karayazı ilçesinde 91/170 kg/da olmuștur. Konya'da il ortalaması olarak verim makarnalık buğdaylarda kuru/sulu koşullarda 286/496 kg/da, ekmeklik buğdaylarda 261/535 kg/da olmuş, ekmeklik buğdayda verim Sarayönü ilçesinde 127 kg/da'a, Taşkent ilçesinde $83 \mathrm{~kg} / \mathrm{da}$ 'a kadar düşmüştür. Şanlıurfa ilinde makarnalık buğdayda verim ortalamas1 suluda $485 \mathrm{~kg} / \mathrm{da}$ iken, kuruda $181 \mathrm{~kg} / \mathrm{da}$, Ceylanpınar'da 164 kg/da'a kadar düşmüştür (Anonim, 2018).

Yukarıda örnek olarak verilen ortalama rakamlardan da açıkça görüldüğü gibi bazı yörelerde buğday verimi çok düşüktür. Ortalama rakamlar yanında, ülkemizde üretici düzeyinde alınan en düşük ve en yüksek buğday verimlerinin, istisnaları bulunmakla beraber, yaklaşık 100-800 kg/da arasında değiştiği kabul edildiğinde, verimdeki varyasyonun çok yüksek olduğu yine açıkça ortaya çıkmaktadır. 
Yeni çeşit/yerel çeşit tercihinde tane verimiyle ilgili bu rakamların ve varyasyonun dikkate alınması yararlı olacaktır. Yüksek verim düzeyine yakın koşullarda, yeni buğday çeşitleri yerine yerel buğday çeşitlerinin tercih edilmesi, geleneksel tarım yapılan koşullar için riskli bir tercih olacak, verim ve ekonomik yönden büyük kayıplar söz konusu olabilecektir. Zaten yüksek verimli koşullarda, özellikle sulu koşullarda, öncelikli olarak örneğin misır tercih edilmekte ve yaygınlaşmakta, yeni çeşitlere bağlı buğday ekim alanları bile giderek azalmaktadır. $\mathrm{Bu}$ nedenle yüksek verimli koşullarda, yerel çeşitlere dayalı buğday üretiminin doğru bir tercih olacağını söylemek oldukça güçtür. Aksine, geleneksel buğday yetiştiriciliği yapıldığı halde düşük verim alınan koşullarda, yerel çeşitlere dayalı buğday üretiminin tercih edilmesi, potansiyel olarak yararlı bir firsat sunmaktadır.

\section{SAP VERIMI}

Eski dünyada, sap verimi daha düşük öneme sahipken, tane verimi ticari yönden asıl arzu edilen unsur olmuş, buna bağlı olarak o dönemde yetiştirilen çeşitler yüksek hasat indeksine sahip olmuşlardır. Avrupa'daki üretim sistemlerinde, bitkilerin hasat edilen kisımlarının öncelik sırasında değişim olmuş, tane verimi önemli olmakla beraber, sap verimi de önemli bir unsur durumuna gelmiştir. Roma ve Orta Çağ dönemindeki üretim sistemlerinde, sap üretimi önemli bir yere sahip olmuş, saplar çok çeşitli amaçlarla kullanılmıştır. $\mathrm{Bu}$ koşullar altında, düşük hasat indeksi olumsuz bir özellik olarak görülmemiştir. Yirminci yüzyılda ise temel ürün tekrar tane olmuş, buna bağlı olarak tane üretiminin artırılması, dolayısıyla hasat indeksinin yükseltilmesi asıl amaç durumuna gelmiştir (Sinclair, 1998). Bu nedenle, günümüzün yeni buğday çeşitleri eski ebeveynlerine kıyasla, daha yüksek hasat indeksine, daha kısa ve sağlam sapa sahip duruma gelmişlerdir.

Başlangıçta sadece ailesel düzeyde tüketime ve öneme sahip olan tahıllar giderek köysel, şehirsel, bölgesel ve ülkesel talep aşamalarından geçmiş, günümüzde küresel düzeyde talep ve öneme sahip, stratejik bitkiler konumuna ulaşmıştır. Başta, artan nüfusun gıda güvenliğinin sağlanması olmak üzere çok sayıda faktör, bu stratejik bitkilerin üretiminin her geçen yıl daha da artırılması yolunda baskı oluşturmaktadır. Bu faktörlerden birisi de biyoyakıt üretimi olup, misır, sorgum ve buğday gibi tahılların kullanılmasında yeni bir talep alanı yaratmıştır. Bu yeni ve alternatif talep alanı, tane veriminden ziyade birim alandan olabildiğince yüksek miktarda biyokütle üretimini esas almaktadır. Benzer şekilde, hayvan beslemede kaba yem ihtiyacının yeşil veya kuru olarak buğday sapından karşılanması istendiği durumlarda, yine sap veriminin yüksek olması istenen bir özellik olmaktadır.

Genelde biyokütle, özelde sap veriminin yüksek olmasının hedeflendiği üretim sistemlerinde: kısa bitki boyuna sahip yeni buğday çeşitleri düşük sap verimi riski taşımaktadır. Aksine, oldukça uzun boylu, fazla kardeşlenen ve yüksek sap verim potansiyeline sahip yerel buğday çeșitlerimiz, bu üretim sistemleri için firsat üstünlüğüne sahip durumdadırlar.

Küresel iklim değişikliğine bağlı olarak: kuraklık etkisinin buğday üretimini tehdit ettiği koşullarda, kısa bitki boyuna sahip yeni buğday çeşitlerinin tercih edilmesinin riskli olacağ 1 vurgulanmas gereken diğer önemli bir husustur. Çünkü zaten kısa olan bitki boyunun, bu koşullarda daha da kısalması, sadece sap verimini değil aynı zamanda tane verimini de olumsuz etkileyecektir. Bu nedenle, genetik olarak uzun boylu ve kardeşlenmelerini, adeta bir sigorta gibi, çevre koşullarına göre ayarlama yeteneğine sahip olan yerel çeşitler, iklim değişikliğinin tehdit ettiği kurak koşullar için de tercih edilme önceliğine sahip olabilirler. Ancak böyle bir tercihte, yerel çeşitlerin daha uzun bir vejetasyon süresine sahip olduğu, tane dolum dönemindeki kuraklıktan olumsuz etkilenebilecekleri riskleri de unutulmamalıdır.

\section{ORGANIK TARIM}

Geleneksel tarımda kullanılan kimyasalların çevre ve insan sağlığı üzerindeki olumsuz etkileri, organik tarıma olan ilgiyi giderek artırmaktadır. Dünyada, son 15 yılda organik tarım giderek artmış (Ponti ve ark., 2012), benzer bir durum ülkemiz için de söz konusu olmuştur. Ülkemizde 
2005 y1lında organik tarımla uğraşan yetiştirici sayıs1 14.401, organik tarım yapılan arazi genişliği 203.811 hektar (doğal toplama alanları dahil), organik bitkisel üretim miktarı 422 bin ton iken, 2017 yılında bu rakamlar sırasıyla 75.067 kişi, 543.033 hektar ve 2,4 milyon tona ulaşmıştır (Anonim, 2018).

Ülkemizin toplam buğday ekim alanı ve üretim miktarı içerisinde, organik buğday henüz çok düşük paya sahiptir. Organik üretim çeşitli zorluklara sahip olmasına rağmen, ülkemiz insanının temel besin kaynağı olan buğdayda, organik üretime de yer verilmesi gerekir. Organik buğday tarımında verimin \% 20-30 kadar düşük olması (Mader ve ark., 2002; Aydın ve ark., 2010) geleneksel buğday tarımına karşı organik buğday tarımının en zayıf tarafını oluşturmaktadır. Ancak, yetiştirme tekniği ve iklim koşulları gibi çeşitli faktörlere bağlı olarak verim farkı sınırlarının değiştiği, geleneksel tarımda verim azaldıkça, organik tarımla aradaki verim farkının da azaldığı belirtilmektedir (Ponti ve ark., 2012).

Buğdayda yeni islah çeşitleri, yüksek girdili geleneksel yetiştiricilik koşullarında seçilmiş olup, organik tarım koşullarına yeterince uyum sağlayamadığ 1 bildirilmiştir (Murphy ve ark., 2007; Wolfe ve ark., 2008). Yeni çeşitler yüksek azot uygulama koşullarında geliştirildiği için, düşük verimli koşullarda eski buğday genotiplerinin yenilerden daha fazla azot kullanabildiği rapor edilmiştir (Foulkes ve ark., 1998). Benzer şekilde fungus ile buğday bitkisi arasındaki mikorizal (simbiyotik) ilişkiler bakımından, eski ve yerel buğdayların yeni 1slah çeşitlerinden daha aktif olduğu belirtilmiştir (Hetrick ve ark., 1993). Allelopati çimlenme, büyüme ve gelişme sırasında bitkilerin kendilerini diğer rekabet ettiği bitkilere karşı koruma olarak geliştirdiği kimyasal bir olay olup, buğdayın çok sayıda allelopatik bileşikler içerdiği ve allelopatik ilişki yönünden genotipler arasında önemli farklar olduğu saptanmıştır (Lammerts van Bueren ve ark., 2011). Diğer bir husus, organik tarıma uygun genotiplerin geliştirilmesinde, genel adaptasyon yeteneğine dayalı seleksiyonlar yerine, özel adaptasyon yeteneğine sahip genotiplerin seçilmesi ve yöresel adaptasyonun esas alınmasının önerilmiş olmasıdır (Banziger ve Cooper, 2001; Ghaouti ve Link, 2009).

Organik buğday tarımında yabancı otların tür ve yoğunluğu artabilmekte (Gosme ve ark., 2012), yabanc1 ot yoğunluğuna bağlı olarak verim \% 40 kadar azalabilmektedir (Mason ve ark., 2007). Son 150 yıllık süreçte, buğday veriminde önemli artış sağlandığ 1 , ancak yabancı otlarla rekabet yönünden yeni çeşitlerde az da olsa bir gerileme söz konusu olduğu (Murphy ve ark., 2008a), kalsiyum dışında tanenin bakır, demir, magnezyum, manganez, fosfor, selenyum ve çinko içeriklerinin yeni çeşitlerde azaldığı, eski çeşitlerde bu elementlerin beslenme açısından ihtiyaç duyulan miktarlarda bulunduğu ifade edilmektedir (Murphy ve ark., 2008b). Yabanc1 otlarla rekabet yeteneği yönünden buğday genotipleri arasında önemli farklar bulunduğu (Hoad ve ark., 2008), uzun boylu, erken gelişmesi hızlı ve fazla kardeşlenen genotiplerin yabancı otlara karş1 daha fazla rekabet üstünlüğüne sahip olduğu bildirilmektedir (Mason ve ark., 2007).

Özet olarak, organik buğday tarımının önündeki zorlukları aşma yönünden; yörelere özgü adaptasyon, yabanc1 otlarla rekabet için uzun boylu olma ve fazla kardeşlenme, allelopatik ve mikorizal özellikler, hastalık ve zararlılara dayanıklılık, yüksek azot ve su kullanım etkinliği, dengeli besin elementi içeriğine sahip olma gibi özellikler aranmaktadır. Yerel buğday kaynaklarımızın, organik tarım yönünden aranan bu ihtiyaçları karşılama potansiyeli çok yüksektir. Nitekim, organik tarımda sorun olan hastalıklara karşı dayanıklı çeşit geliştirmede, uzun boylu eski çeşitlerden yararlanılmaktadır (Murphy ve ark., 2007; Lammerts van Bueren ve ark., 2011). Yerel buğdaylarımız, tarımsal kimyasal kullanımının söz konusu olmadığ1, binlerce yıllık süreçte, yani organik tarım yapılan koşullar altında seçilerek bugünlere taşınmıştır. $\mathrm{Bu}$ nedenle, organik buğday tarımının yapılacağı koşullar için yerel buğdaylarımız çok özel bir firsat sunmaktadır.

\section{KALITE ve YEREL TALEPLER}

Günümüzde kamuoyunda, yeni 1slah çeşitlerine kıyasla yerel buğdayların daha besleyici olmasının yanı sıra gluten içermediği şeklinde bir kabul söz 
konusudur. Tüketiciler arasında giderek yaygınlaşan bu kabul, yerel buğday çeşitlerinden yapılan ürünlere karşı giderek artan bir talep yaratmış, yerel çeşitlerin gündeme gelmesinde büyük bir paya sahip olmuştur. Konu bilim dünyası tarafından da gündeme alınmış, çeşitli araştırmalar yapılmış ve yapılmaya devam edilmektedir.

Son y1llarda özellikle Siyez gibi eski buğdayların gluten içermediği, bu nedenle de çölyak hastalarının bu eski buğdayları güvenle tüketebileceği yönünde yanıltıcı iddiaların bulunduğu bildirilmiştir (Koksel ve ark., 2016). Hem yerel hem de modern buğdaylarda bulunan gluten ( $\alpha$-gliadin fraksiyonu), çölyak hastaları tarafından tüketilememektedir (Colomba ve Gregorini, 2012). Yapılan çalışmalarda, Siyez (Gianfrani ve ark., 2012), Graziella Ra ve Kamut (Colomba ve Gregorini, 2012) gibi eski buğdayların da $\alpha$-gliadin içerdiği ve çölyak hastaları için toksik olduğu belirtilmiștir. Ülkemizde yetiştirilen yerel (Sünter, Karakılçık, Siyez) ve modern (Tosunbey) buğday çeşitlerinin gluten ve gliadin içeriklerinin belirlendiği bir çalışmada ise, Siyez dahil eski buğday çeşitlerinin gluten içerdiği, hatta eski buğdaylardan Sünter'in hem gliadin hem de gluten miktarının Tosunbey ekmeklik buğday çeşidinden daha fazla olduğu tespit edilmiştir (Çetiner ve ark., 2018).

Besleyicilik bakımından yapılan çalışmalarda ise, kavuzlu buğdayın magnezyum, selenyum, fosfor, çinko, demir, manganez ve bakır içeriklerinin, yeni çeşitlerden daha yüksek olduğu (Piergiovanni ve ark., 1997; Erba ve ark., 2011), Khorasan (Kamut) buğdayının ise \% 20-30 fazla protein, \% 65 fazla amino asit, yüksek mineral madde ve lipit oranına sahip olduğu bildirilmektedir (Michalcova ve ark., 2014).

Yapılan bir çalışma, eski buğdayların yeni buğdaylardan daha sağliklı olduğu hipotezini desteklemese de kaplica, gernik ve Khorasan buğdaylarının karotenoid bakımından ekmeklik buğdaylardan daha zengin olduğunu ortaya koymuştur (Shewry ve Hey, 2015). Kavuzlu ve kavuzsuz gerniğin, 2 ticari çeşitle, öğütülmeden ve öğütülerek karşılaştırıldığ 1 bir çalışmada kavuzlu gerniğin, ögütme öncesi ve sonrasında; toplam çözünebilir fenolik içeriği, antioksidan içeriği ve anti-hiperglisemik özellikleri bakımından üstün olduğu, kronik hiperglisemi ve tip-2 diyabet hastalığının erken dönemlerinde besinlere entegre edilebileceği sonucuna varılmıştır (Christopher ve ark., 2018). Eski buğdayların yüksek $\mathrm{Mg}, \mathrm{Zn}, \mathrm{K}$ ve Se içeriğine sahip olduğu, ayrıca yüksek amiloz ve düşük amilopektin içerikleri nedeniyle glukoz ve insülini azalttığ1, böylece uzun süre tokluk hissi verebildiği, toplam ve LDL kolestrolü azalttığ 1 , antioksidan parametrelerini artırdı $\breve{g}$, zararlı sitokininleri azaltıp, faydalı sitokininleri artırdığı bildirilmektedir (Dinu ve ark., 2018).

Kavuzlu buğdaylarda protein oranı yüksek olmakla beraber, protein kalitesi düşük olduğundan, kaliteli ürünler yapabilmek için özel yöntemlere ihtiyaç duyulduğu (Longin ve ark., 2016; Frakolaki ve ark., 2018), bitki 1slahının besinsel lif içerikleri (arabinoksilan ve $\beta$-glukan) yönünden makarnalık buğdaylarda olumsuz etki yapmadığı şeklinde sonuçlar da söz konusudur (De Santis ve ark., 2018).

Yukarıda özetlenmeye çalışılan sonuçlar, eski buğdayların bazı besin elementi içeriği yönünden üstün olduğunu bilimsel olarak ortaya koymaktadır. Fakat, sağlık yönünden daha güvenilir ve genel kabul görebilir sonuçlara ulaşabilmek için çok daha ileri düzeyde araştırmalara ihtiyaç vardır (Shewry, 2018). Bilimsel çalışmalar yanında tüketiciler arasında yerel buğdaylardan yapılmış ürünlere karşı ilginin artıyor olması da yerel buğdaylar için ümit verici bir firsat sunmaktadır. $\mathrm{Bu}$ firsat, üretici ve tüketiciler için memnuniyet sağlayabilecek fiyat dengelemesi ve uygulamalarıyla birleştirilebilirse, yerel buğday çeşitlerinin üretiminde ekonomik düzeyde önemli artışlar sağlanabilir.

\section{SONUÇ ve ÖNERILER}

Bitki 1slahı bakımından çok önemli bir gen kaynağ1 durumunda olan yerel buğday çeşitlerimiz, ekonomik düzeyde buğday üretimi yönünden de firsatlar sunmaktadır. Buğday üretimi yönünden, yeni çeşitlerle eski çeşitlerin olumsuz yönleri ön plana çıkarılarak, bir diğerini değersiz kılıcı 
karşılaştırmaların yapılması uygun değildir. Olumsuz yaklaşımlar yerine, koşullara göre hangisinin tercih edilmesinin doğru olacağı konusu üzerinde durulmalıdır. Ülkemiz insanının temel besin kaynağı olan buğdayın, y1llık üretim miktarını riske sokabilecek yönlendirmelerden ve tercihlerden uzak durulmalı, gıda güvenliği yönünden yüksek verim potansiyeline sahip yeni buğday çeşitlerinin önemi unutulmamalıdır. Bu nedenle, yüksek verim potansiyeline sahip ekolojik koşullarda, yeni çeşitler yerine yerel çeşitlerin tercih edilmesi riskli

\section{LITERATÜR LISTESI}

Akkaya, A. 2008. Tahılın kalbi Konya'dan çağrı. Ülkesel Tahıl Sempozyumu. 2-5 Haziran 2008. Konya. s.1-13.

Alp, A. ve C. Akıncı. 2005. Diyarbakır ili ve çevresinden toplanan buğdaygil genetik kaynaklarının karakterizasyonu. Türkiye VI. Tarla Bitkileri Kongresi. 5-9 Eylül 2005. Antalya. Cilt 2: 675-678.

Alp, A. ve E. Kün. 1999. Güneydoğu Anadolu Bölgesi yerel makarnalık buğday çeşitlerinin tarımsal ve kalite karakterleri üzerinde araştırmalar. Türkiye 3. Tarla Bitkileri Kongresi. 15-18 Kasım 1999. Adana. s.103108.

Alp, A. ve H. Aktaş. 2005. Güneydoğu Anadolu Bölgesi'ndeki buğdaygil genetik kaynaklarının toplanması, karakterizasyonu ve ön değerlendirme. GAP IV. Tarla Bitkileri Kongresi. 21-23. Eylül 2005. Şanlıurfa. Cilt 1: 763-768.

Anonim. 2018. Türkiye İstatistik Kurumu. http://www.tuik. gov.tr. (Erişim tarihi 10 Eylül 2018).

Ashby, J. A. 2009. The impact of participatory breeding. pp. 649-671. In: S. Ceccerelli, E. P. Guimaraes, and E. Weltzien (Eds.). Plant Breeding and Farmer Participation. FAO, Rome, Italy.

Aydın, M., M. Yılmaz, A. Ç. Kara ve S. Soylu. 2010 Ekmeklik buğdayda organik ve konvansiyonel yetiştiriciliğin karşılaş̧tırması üzerine bir araştırma. Türkiye IV. Organik Tarım Sempozyumu. 28 Haziran1 Temmuz 2010. Erzurum. s. 102-106.

Aykas, L. ve A. Tan. 2018. Türkiye kaplıca buğday yerel çeşitlerinin çiftçi elinde in situ muhafazası. Türkiye örneği. Türkiye Yerel Buğdaylar Sempozyumu. 20-22 Aralık 2018. Bolu. s. 85-86.

Banziger, M., and M. Cooper. 2001. Breeding for low input conditions and consequences for participatory plant breeding: Examples from tropical maize and wheat. Euphytica 122: 503-519. olacaktır. Buna karşılık eski yerel çeşitlerimiz; geleneksel yetiştiricilikte düşük verim alınan koşullar için, sap üretiminin yüksek olmasının istendiği durumlar için, yerel taleplerin yüksek olduğu yöreler için, özelliklede organik buğday tarımının yapılacağı işletmeler için ekonomik üretim firsat ve potansiyeline sahiptir. Bilimsel ve üretici katılımlı çalışmalarla bu fursatlar ve potansiyeller değerlendirilebilir, yerel buğdaylara dayalı ekonomik ve sürdürülebilir üretim sağlanabilir.

Christopher, A., D. Sarkar, S. Zwinger, and K. Shetty. 2018. Ethnic food perspective of North Dakota common emmer wheat and relevance for health benefits targeting type 2 diabetes. Journal of Ethnic Foods 5 (1): 66-74.

Çetiner, B., S. Tömösközi, E. Schall, A. Salantur, and H. Köksel. 2018. Comparison of some landraces and a modern wheat in terms of quality, functional properties and gluten/gliadin content. p. 92. In: LACC $4,4^{\text {th }}$ ICC Latin American Cereals Conference. 11-14 March 2018. Mexico City, Mexico.

Colomba, M. S., and A. Gregorin. 2012. Are ancient durum wheats less toxic to celiac patients? A study of $\alpha$ gliadin from Graziella Ra and Kamut. The Scientific World Journal 2012: 837416.

Damania, A. B., L. Pecetti, C. O. Qulset, and O. B. Humeid. 1996. Diversity and geographic distribution of adapt and traits in Triticum turgidum L (durum group) wheat landraces from Turkey. Genetic Resources and Crop Evolution 43 (5): 409-442.

De Santis, M. A., O. Kosik, D. Passmore, Z. Flagella, P. R. Shewry, and A. Lovegrove. 2018. Comparison of dietary fibre composition of old and modern durum wheat (Triticum turgidum spp. durum) genotypes. Food Chemistry 244: 304-310.

Dinu, M., A. Whittaker, G. Pagliai, S. Benedettelli, and F. Sofi. 2018. Ancient wheat species and human health: Biochemical and clinical implications. Journal of Nutritional Biochemistry 52: 1-9.

Erba, D., A. Hidalgo, J. Bresciani, and A. Brandolini. 2011. Environmental and genotypic influences on trace element and mineral concentrations in whole meal flour of einkorn (Triticum monococcum L. subsp. monococcum). Journal of Cereal Science 54: 250-254.

Foulkes, M. J., B. Sylvester, and R. K. Scott. 1998. Evidence for differences between winter wheat cultivars in acquisition of soil mineral nitrogen and uptake and utilization of applied fertilizer nitrogen. Journal of Agricultural Science 130: 29-44. 
Frakolaki, G., V. Giannou, E. Topakas, and C. Tzia. 2018 Chemical characterization and breadmaking potential of spelt versus wheat flour. Journal of Cereal Science 79: $50-56$.

Ghaouti L., and W. Link. 2009. Local vs. formal breeding and inbred line vs. synthetic cultivar for organic farming: Case of Vicia faba L. Field Crop Research 110: 167172 .

Gianfrani, C., M. Maglio, V. Rotondi Aufiero, A. Camarca, I. Vocca, G. Iaquinto, N. Giardullo, N. Pogna, R. Troncone, S. Auricchio, and G. Mazzarella. 2012. Immunogenicity of monococcum wheat in celiac patients. The American Journal of Clinical Nutrition 96: $1339-1345$.

Gosme, M., M. Villemandy, M. Bazot, and M. H. Jeuffroy. 2012. Local and neighbourhood effects of organic and conventional wheat management on aphids, weeds, and foliar diseases. Agriculture, Ecosystems and Environment 161: 121-129.

Hammer, K., and A. Diederichsen. 2009. Evolution, status and perspectives for landraces in Europe. pp. 23-44. In: M. Veteläinen, V, Negri, and N. Maxted (Eds.). European Landraces Onfarm Conservation, Management and Use. Bioversity Technical Bulletin No. 15. Bioversity International, Rome, Italy.

Hetrick, B. A. D., G. W. T. Wilson, and T. S. Cox. 1993. Mycorrhizal dependence of modern wheat cultivars and ancestors-synthesis. Canadian journal of Botany 71: $512-518$

Hoad, S., C. Topp, and K. Davies. 2008. Selection of cereals for weed suppression in organic agriculture: A method based on cultivar sensitivity to weed growth. Euphytica 163: 355-366.

Kandel, H. J., P. M. Porter, P. M. Carr, and S. F. Zwinger. 2008. Producer participatory spring wheat variety evaluation for organic systems in Minnesota and North Dakota. Renewable Agriculture and Food Systems 23: 228-234.

Karademir, Ç. ve A. Sağır. 1999. Güneydoğu Anadolu Bölgesinde makarnalık buğday (Triticum durum) genotiplerinde kimi bitkisel özelliklerin değişim sinırları. Türkiye 3. Tarla Bitkileri Kongresi. 15-18 Kasım 1999. Adana. s. 360-365.

Karagöz, A. 1998. In situ conservation of plant genetic resources in Ceylanpinar state farm. pp. 87-91. In Proceeding of the International Symposium on in Situ Conservation of Plant Genetic Diversity. Ankara.

Karagöz, A. 2018. Yerel çeșitlerin çiftçi elinde korunması. Türkiye Yerel Buğdaylar Sempozyumu. 20-22 Aralık 2018. Bolu. s. 21-22.

Karagöz, A. ve İ. Özberk. 2010. Türkiye'de makarnalık buğday genetik kaynakları ve bu kaynakların buğday ıslahında kullanılması. Makarnalık Buğday ve Mamulleri Konferans1. 17-18 May1s 2010. Sanliurfa. s.67-74.
Karagöz, A. ve N. Zencirci. 2004. Variation in wheat (Triticum spp.) landraces from different altitudes of three regions of Turkey. Genetic Resources and Crop Evolution 52: 775-785.

Koksel, H., B. Cetiner, and T. Sanal. 2016. Misleading claims and scientific assessment about grain products. Tusaf Journal 1: 48-60.

Lammerts van Bueren, E. T., S. S. Jones, L. Tamm, K. M. Murphy, J. R. Myers, C. Leifert, and M. M. Messmer. 2011. The need to breed crop varieties suitable for organic farming, using wheat, tomato and broccoli as examples: A review. NJAS-Wageningen Journal of Life Sciences 58: 193-205.

Longin, C. F. H., J. Ziegler, R. Schweiggert, P. Koehler, R. Carle, and T. Würschum. 2016. Comparative study of hulled (einkorn, emmer, and spelt) and naked wheats (durum and bread wheat): Agronomic performance and quality traits. Crop Science 56: 302-311.

Mader, P., A. Fliessbach, D. Dubois, L. Gunst, P. Fried, and U. Niggli. 2002. Soil fertility and biodiversity in organic farming. Science 296: 1694-1697.

Mason, H. E., A. Navabi, B. L. Frick, J. T. O'Donovan, and D. M. Spaner. 2007. The weed competitive ability of Canada Western Red Spring Wheat cultivars grown under organic management. Crop Science 47: 11671176.

Michalcova, V., R. Dusinsky, M. Sabo, M.A. Beyroutiova, P. Hauptvogel, Z. Ivanicova, and M. Svec. 2014. Taxonomical classification and origin of Kamut wheat. Plant Systematics and Evolution 300: 1749-1757.

Murphy, K. M., J. C. Dawson, and S. S. Jones. 2008a Relationships among phenotypic growth traits, yield and weed suppression in spring wheat landraces and modern cultivars. Field Crops Research 105: 107-115.

Murphy, K. M., P. G. Reeves, and S. S. Jones. 2008b. Relationship between yield and mineral nutrient concentrations in historical and modern spring wheat cultivars. Euphytica 163: 381-390.

Murphy, K. M., K. G. Campbell, S. R. Lyon, and S. S. Jones. 2007. Evidence of varietal adaptation to organic farming systems. Field Crops Research 102: 172-177.

Özdemir, F., M. Küçükçongar, A. Morgounov, M. Keser, M. Kan, H. Müminjanov ve C. Qualset. 2018. Anadolu'nun genetik hazinesi "yerel buğdaylar". Türkiye Yerel Buğdaylar Sempozyumu. 20-22 Aralık 2018. Bolu. s. 32-33.

Piergiovanni, A. R., R. Rizzi, E. Pannacciulli, and C. D. Gatta. 1997. Mineral composition in hulled wheat grains: A comparison between emmer (Triticum dicoccon Schrank) and spelt ( $T$. spelta L.) accessions. International Journal of Food Sciences and Nutrition 48 (6): 381-386.

Ponti, T., B. Rijk, and M. K. Ittersum. 2012. The crop yield gap between organic and conventional agriculture. Agricultural Systems 108: 1-9. 
Salantur, A. 2018. Köy çeşitleri ve buğday 1slahı. Türkiye Yerel Buğdaylar Sempozyumu. 20-22 Aralık 2018. Bolu. s. 27-29.

Shewry, P. R. 2018. Do ancient types of wheat have health benefits compared with modern bread wheat? Journal of Cereal Science 79: 469-476.

Shewry, P. R., and S. Hey. 2015. Do "ancient" wheat species differ from modern bread wheat in their contents of bioactive components? Journal of Cereal Science 65: 236-243.

Sinclair, T. R. 1998. Historical changes in harvest index and crop nitrogen accumulation. Crop Science 38: 638643 .

Sudutan, T. 2009. Malatya yöresinde yetiştirilen Kunduru1149 buğday popülasyonunda bazı morfolojik ve fenolojik karakterler yönünden varyasyon. Yüksek Lisans Tezi. K. S. Ü. Zir. Fak. Fen Bil. Ens. Tarla Bitkileri Ana Bilim Dalı Kahramanmaraş.
Tan, A. 2018. Buğday yerel çeşitlerinin geleneksel bilgileri. Türkiye Yerel Buğdaylar Sempozyumu. 20-22 Aralık 2018. Bolu. s. 25-26.

Wolfe, M. S., J. P. Baresel, D. Desclaux, I. Goldringer, S. Hoad, G. Kovacs, F. Löschenberger, T. Miedaner, H. Ostergard, and E. T. Lammerts van Bueren. 2008. Developments in breeding cereals for organic agriculture. Euphytica 163: 323-346.

Yıldırım, A., A. Sayaslan, N. Kandemir, T. Eserkaya, M. Koyuncu ve Ö. A. Sönmezoğlu. 2008. Makarnalık kalitesini etkileyen genlerin Türk makarnalık buğday çeşitlerindeki durumu. Ülkesel Tahıl Sempozyumu. 25 Haziran 2008. Konya. s. 381-389.

Zencirci, N. 1995. Türkiye makarnalık buğdaylarının önemli karakterleri üzerinde araştırmalar. Doktora tezi. A. Ü. Zir. Fak. Fen Bil. Ens. Tarla Bitkileri Ana Bilim Dalı Ankara.

Zencirci, N. 2018. Buğdayın sılası Türkiye'dir. Türkiye Yerel Buğdaylar Sempozyumu. 20-22 Aralık 2018. Bolu. s. 13. 